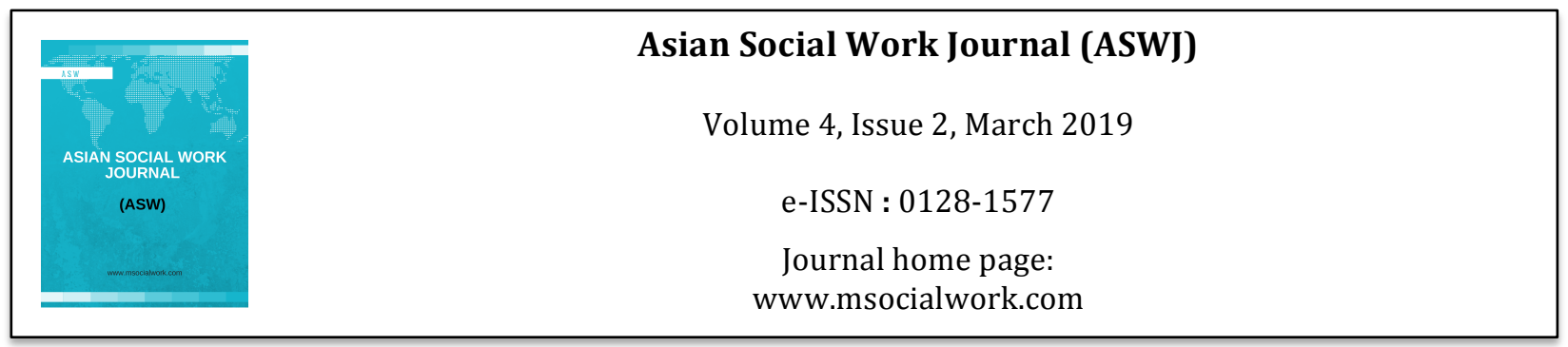

\title{
Developing Healthy Environment for Young Mothers in Suburb Indonesia
}

\author{
Sari Viciawati Machdum ${ }^{1}$, Fardhan Zaka Ramzy ${ }^{1}$, Anna Amalyah Agus ${ }^{1}$, Annisah ${ }^{1}$ \\ 1 Universitas Indonesia, Indonesia \\ Corrrespondence: Sari Viciawati Machdum (sari.viciawati@ui.ac.id)
}

\begin{abstract}
This article explores community services approach that intends to change the behavior of young mothers at home in serving food for their families. Research results showed that there were challenges in this suburb area., especially for young mother who can get many facilities to get their daily meals. Unfortunately, the facilities could give negative impacts on them in gaining proper nutrition. The obstacles came from many aspects of society. Thereupon, social intervention for them needs to be handled carefully so that the beneficiaries could get sustainable change. Others have argued that participation is crucial elements in community intervention. This research showed that participation its self is the hard aspect in the suburb especially at the region that has rapid development but lack of social investments. People used to get many projects from different organizations. The helping projects often did not consider sustainability matters. This condition reshapes the people. They become the object of social programs. Maintaining intensive programs based on some practices: collaboration planning and implementation could increase the trust of the beneficiaries. Based on our study on ten young women and other fourteen participants in a suburb of Indonesia, trust is primary material in changing people's behavior. Especially educating people to live in healthy lifestyle as a vital aspect of developing a healthy environment.
\end{abstract}

Key words: healthy environment, motherhood, community services approach, trust, suburb area, social marketing

\section{Introduction}

The fulfillment of nutrition for families has often seen as a problem with a basic reason: not having an adequate economic ability (Ulfani, et al. 2011). Family financial capacity does not always guarantee the fulfillment of balanced nutritional needs for each family member. Mufidah (2012) also explained that economically well-established families could experience nutrition problems. El-Maryam said that the issue of nutrition in families that can occur because they have the risk of obesity. Moreover, the technology development nowadays makes it easy for families to reach ready-to-eat food or instant food where frequently lack nutritional content.

If an economic-established family is at risk for nutritional problems, the one with economic constraints also needs to be examined further. They do not have access to indulgent technology to get the ready-toeat foods that are less nutritious immediately. However, in their home which located in a dense environment, there will be a merchant who was selling fast food like instant noodles or frozen foods. Regarding this instant noodle, Fitriani (2018) mentions the risk of eating instant noodle. Beside does not have enough nutrition, instant noodle also cause harmful diseases. 
For being inexpensive meals, instant noodles are often chosen as daily food. Consumers get satisfied by consuming it owing to its fast, economical and easiness to cook, without realizing its negative impact for their health. Other meals that sold by street vendors also have adverse effects. Based on research from Gultom, Onibala et al. (2018), the consumption of unhealthy meals that are often carried out by elementary school children has a positive relation onship with diarrhea in children.

The danger of consuming instant food does not provide a risk to the body. Snacking habits will also have a negative impact on the family's financial condition. For the stable financial families, the harmful effects of the food will lead to diseases that can have a negative financial impact in the future. One of the examples, it can be seen when family members get a cancer disease which the treatment is costly.

As outlined in the discipline of household economics, understanding of finance (financial literacy) and the ability to manage household aim to improve the welfare of the family as the smallest unit in a state. Bongomin et al. (2017) argued that the aspect of excellent financial management is a very influential component in increasing understanding of finance, while sufficient knowledge of finance influences the inclusive financial strategy. Financial institutions within the framework of improving the welfare of low-income people are the majority untouched by the Institute finance. The findings of Bongomin et al (2017) in Uganda are also in line with the findings of Salleh in Brunei (2015) which suggested that lower income people have a lower understanding of finance than the higher income people.

A Non-Governmental Organization in Depok in their study (FGD, 24 Februari 2017), found that lowincome families in an area in Depok City had a low level of financial understanding, which was exacerbated by the ability to manage households, also at cooking. This preliminary finding can be seen in the families that prefer to buy the instant food both in the form of meals and snacks rather than cooking themselves. Even though making homemade food is estimated to be cheaper at least $50 \%$ than buying processed food. Studies related to the ability to cook are more associated with issues of the fulfillment of nutrition and health problems such as research conducted by McDowell, McMahunBeattie \& Burns (2015) and Worsley et al. (2015). There is no specific discussion about the relation of cooking ability with the household welfare.

In this research, a multidisciplinary approach consists of a financial, nutritional, social and psychological approach was used to address young mother problems in the Depok area. The financial understanding program conducted in the first session of the program. This training is intended to cultivate an idea that a good family financial management supported by cooking skills makes it possible to improve family welfare. A prosperous family can increase the opportunity for children to get higher education because of the saving process, enhance health because nutrition and food quality are more maintained and increase happiness through healthy and yummy food.

In the first session, the participants educated with two topics. The first one is about balancing the expenditure ratios regarding of four things: daily expenses, debt repayments, savings, and lifestyle that referred from International Financial Planner Association Guidelines (Financial Planning Standard Board International). Second, participants facilitated a discussion on how the financial, health, education and family happiness conditions were related to each other. Implicitly, at the end of the session, they conveyed that the ability to cook could improve the quality of these four things. This first session became an introduction before the session on understanding nutrition and developing cooking skills which expected for every family/mother involved to make their homemade dishes that are tasty, nutritious and affordable. As a result of this research process, the participating mothers stated that the increase in cooking skills and supported by the community of the Whatsapp forum had a positive impact on the financial side. However, in the process of intervention, the effort to implementing the social services turned out into a dynamic process especially for mothers who live on the edge of the city who have received various kinds of services from multiple organizations, both government and non-government. 


\section{Research Method}

This study used action research method which consists of 3 main stages: look, think and act (Stringer, 1999). Twenty-four (24) informants, including ten of beneficiaries and eighteen supporting informants contributed to this research. They came from government organizations, health workers, academics, practicioners and the private sector. This research conducted start from 2017 to 2018 (longitudinal study). Through a participatory process, researchers maintain the quality of data by using several trusworthiness stratigies: triangulation, member checking, peer examination, and interview technique (Machdum, Agus, Ramzy \& Zafira, tt; Krefting 1991).

\section{Findings}

\section{Participation as primary elements in community intervention}

In any kind of model, community participation is a vital element of community practice intervention. Without the involvement of people in community, the sustainability of program will be difficult to achieve. The problem is that cooperation is a challenge. It is not easy to organize people especially in suburban communities. The solidarity of community has begun to decrease at sub urban. The members of community no longer take mutual interests as important matter in life. The relation between community become more transactional.

In the process of implementing social services, knowledge about people in sub urban becomes essential for the provision of social workers who will carry out social interventions at the community level. Expertise related to the community context will help social workers to be able to adjust better the values and theories that will be used to practice. On the other hand, social workers must also have to be aware that basic knowledge related to the context should not make them have negative perceptions of the attitudes and behavior of the people who will become partners to implement change.

Changing efforts that emphasize the potential of the community will get various obstacles if social workers already have a negative perception of service recipients. Basic knowledge about the context of society including social, cultural and political conditions is essential for social workers. However, in practice, this knowledge does not produce negative perceptions. After identifying problems and needs, social workers will get accurate data to validate the findings of community knowledge who will be the participants in the intervention process. Such knowledge is needed for social workers to be aware of who they are, but do not make social workers have negative perceptions that lead to labeling.

Some knowledge that can lead to a negative perception for social workers in the community work is knowledge about participants, as follows: lazy to participate and challenging to work together. This knowledge has gained triangulation. However, social workers cannot save it as a tool to judge the targeted beneficiaries. Conversely, social workers should be able to make knowledge from the results of the assessment a basis for developing a program that can provide more benefits to service recipients. Through positive thinking like this, social workers can build their 'art' aspects of interacting with the community.

Society as a collection of "self" is also dynamic and not linear (Fitzpatrick, 2005). Various changes also cannot be easily predicted. When partnering with social workers, the changes that occur in society expected to be in a more positive direction. In this case, there is one value in social work that needs to be done, namely the value that emphasizes that the community has the right to make its own choices. Social workers in the context of the community do not necessarily carry out their roles as experts who can provide judgments and give "medicines" based on their "diagnosis" or perspective.

The perception of social workers towards the community has an impact on their choice of attitude and role when together with the city. Acting as an expert in the community does not mean a bad choice. However, in the context of social intervention at the community level, the role of social workers as an expert will lead to different responses from the community. The role of an expert will make the 
community passive or worse they will become defensive. This condition will harm many parties especially when it happened in the early stages of social intervention. The role of social workers as an expert, on the one hand, makes people scared to share what their thoughts and feelings. That is why social workers also have to be aware about the skills of social workers as mentioned by National Association of Social Workers (Fahrudin, 2014).

Not only for adults, but even children are also individuals who have the potential to be creative. Social workers must also be wiser when interacting with various professions. Even meet with health workers who usually have experience in the community with adequate knowledge from various types of training from the government and non-government institutions. Through the approach to adult education, social workers can provide a stimulus that can lift these potentials. Thus, the community can decide to contribute based on their respective ways positively.

Positive perceptions of the community as recipients of services have the potential to get positive feedback from the community itself. If they give a positive response and acknowledge the benefits of the program, the community will undoubtedly participate actively and cooperate in carrying out activities. Finding in the "look" stage of this study, the social worker who were involved decided to have positive perception toward the community and choose andragogy approach in the process. This decision made social workers, other professionals in team, and also stakeholders not to focus on the individual matters. Furthermore, change agents decided to identified the needs and problems at the community in a broader way: also through organization and policy level. This study found the social institutions that have been delivering social services at the research location. Moreover, social workers in this study also assessed health services institutions. Thus, the development of a healthy environment received systemic support from various levels in the community. As stated by Fahrudin (2014, p. 68), empowerment for marginal society in order to eliminate the obstacle that come from structural limitation.

\section{The suburb area: lack of trust and the matters of religion in practice}

The challenge when implementing social interventions in urban areas was the awareness and knowledge about the value and solidarity decreasing in community. The social interaction was more limited due to the nature of the urban society that prioritizes the "I" aspects (Khaldun in Amirin, 2016). On the other hand, social workers who also had biological, psychological, social and spiritual needs must also prioritize the application of the value of their profession in carrying out their duties. In the condition of a community that lacks social investment in the aspect of "trust," one challenge of social workers is to foster a "value" that begins to fade to reconcile social functioning in social groups in the community.

Before growing the aspect of "value" in society, social workers need to fight for the value of their profession. The professional value of social workers is significant for the initial process, especially in the process of engagement. Even though one of the researchers had engaged and carried out previous activities, the re-engagement and re-assessment needed to be carried out again.

Value is our knowledge of what is good and bad. The application of the value of social workers in community empowerment also adjusted to the values that exist in society. Allen Pincus and Anne Minahan (in Zastrow, 2010, p. 97) interpret values as:
"beliefs, preferences, or assumptions about what is desirable or good for [humans]. An example is the belief that society has an obligation to help each individual realize his fullest potential. They are not assertions about how the world is and what we know about it, but how it should be."

In the practice of social work, there are 8 crucial values: Respect for the Integrity and Individuality, Self-Determination, Confidentiality, Advocacy and Social Action for the Oppressed, Accountability, The Institutional Orientation, Respect for the Spiritual and Religious Beliefs of Other, and Promoting Social and Economic Justice, and Safeguarding Human Rights (Zastrow, 2010). These values are part 
of the basic guidelines in carrying out social work practices. So that in unexpected situations, social workers can make good decisions following the context in society.

Bloom in Robbins, S., Chatterjee, P., Canda. E.R., (2006, p. 4) defines the context as a place and social group where human behavior is ... the framework can include biological, physical, psychological, social, cultural, spiritual, economic, political and historical. The context in the next community intervention activity needs to be a concern because each background is unique. Healy (2005) sees the context in social intervention as a crucial part of values and theory/knowledge. Without an understanding of the context, theories and skills in social intervention become less useful. Social workers must negotiate their skills and knowledge based on the context in which social problems or issues occur.

On the other hand, values in the profession of social work are inherent in practice. Not only social workers, but other professions engaged in social welfare also need to implement fundamental values in interacting with the community. However, in certain situations, practicing the value of this profession becomes difficult because of various unexpected conditions that are often encountered when interacting in society. In overcoming these problems, Social Welfare Sciences itself recognizes spiritual aspects in implementing social interventions. So, welfare does not only cover biological, psychological, and social aspects. Spiritual aspects are also an essential part of the process of social intervention, including for community empowerment activities.

Related to spiritual concepts, academicians have distinguished between spiritual and religious meanings. The difference in spiritual and religious aspects lies in the boundaries of religion which are considered more institutionalized than spiritual matters. Spiritual elements are also more defined by various universal problems. Thus, the religious aspect is general, abstract and can involve anyone as well as good for humans. Every human being can do good. The presence of goodness can be any form in the world. Similarly, the presence of sunlight is always available on the face of the earth.

On the one hand, the spiritual urgency in the practice of social work is not only for the restoration of social functioning for service recipients. Social workers also need spiritual aspects in carrying out social interventions. Moreover, the process of change practices plans to absorb social workers. In the early days of the emergence of the science of social work, the separation between religion and science made the process of the practice of social work more empty. Belief in the presence of almighty, enthusiasm in giving assistance can emerge (Payne, 2005).

On the other hand, the view that sees religion as different from the spiritual aspect defines religion as institutionalized value. For example, religion has a variety of rules for conducting worship (Armstrong, 2010). Though religion itself is also broad, and even includes the spiritual aspects. Thus, the spiritual aspect cannot be separated from religion. Even in the practice of social work, the religious aspect cannot be separated from the process of providing assistance because through a good understanding of religion, social workers can obtain sufficient energy and knowledge in making changes in society. This goodness is not even just for himself. However, also for other people and even the universe. The presence of elements of faith in living religion can make social workers apply their knowledge more flexible.

A flexible attitude in interacting with the community can occur because religion is an integral part of life. Even from childhood. Social workers or even other professions as change agents become not "textbook" based because there are basic guidelines that have been embedded in workers heart. In fact, with knowledge based on religious beliefs, social workers can simplify their knowledge to be more grounded by sufficiently good behavior and good intentions to learn together with the community. Scientifically, it automatically manifests itself in interacting with the community. The sincerity of social workers as agents of change will be read by itself. "Trust" as one of the essential elements in developing community participation will be built by itself.

Back to the value for social workers, sensitivity to the context in which social intervention is implemented is a crucial problem. Not all values in the profession of social workers can be applied. In 
relation to the development of a healthy environment in the community for urban and suburban mothers, social workers need to conduct an analysis when carrying out engagement and assessment of the value to be used. In this study, a crucial value to be implemented is: respect for the dignity and uniqueness of the individual, as well as confidentiality

Respecting the dignity and uniqueness of the community is essential in carrying out each stage of community empowerment. Based on the results of the research, especially in the "think" stage of action research, this value has become a fundamental aspect for social workers in implementing engagement and re-assessment. Social workers have gained prior knowledge from various informants regarding the character of the people who are the recipients of services. Based on the value of individualization, social workers must carry out triangulation.

Data from "look" activities in this action research can be an insight to interact with the community. As mentioned earlier, the data may not affect the perception of social workers towards the community. Moreover, social workers intend to empower the community. Negative perceptions do not support behavior change in community empowerment activities. Especially in the early stages of action research: "look" and "think." The fruitfulness of social interaction in this part has impacts on subsequent triumph. Not only for the success of the "act" stage. That stage also determines the success of the follow-up cycle in action research.

Besides respect for the dignity and uniqueness of the individual, other important values are confidentiality. Secrecy is a crucial problem in service delivery because people are also human. They also need to get restrictions, especially in this action research. Society is primarily a participant who needs to be seen as a subject and not merely an object. Secrecy is a sensitive problem, and it even becomes the heart of the service delivery process because its implementation determines the existence of "trust" itself.

Moreover, in the era of information society like nowadays, data obtained from the community cannot be objects that can be shared on social media. Various tools in computer and cellphone technology can hurt faded trusts in suburban communities. One of the activities that must be carried out in brings out confidentiality in this action research is to disseminate the informed consent to the participants of the study especially the research participants who were intensively involved in this study. The informed consent sheet has become very common especially for parties who are indeed obliged to publish community empowerment activities as implemented by social workers in this study. However, even though social workers in this activity use informed consent, various information in the process of activities needs to be considered. For example related to the confidentiality of names, the emergence of children's photos, pictures of people who did not sign informed consent and the other things. Except when the communities involved have expressed their willingness to publish the results of activities on social media to spread knowledge and kindness to the people.

The last important value in developing "trust" in society was accountability. Accountability in this study was carried out in the "look" and "act" stages by holding pre-test and post-test based on the objectives of the activity: behavior change for participants in managing finances and providing food at home. The change in behavior in participants shows the usefulness of this research activity for the community.

\section{Discussion}

\section{Maintaining intensive programs based on collaborative planning and implementation}

While related to the provision of food at home, social marketing activities require experts who educates the beneficiaries. They have to be the experts of some fields, such as psychology, social and health (especially nutrition). For some aspect for the field of psychology and social sciences, social workers could bring their roles as educators. In practice, social workers provide material that can be a model 
and motivation for service recipients. The social worker who becomes the educator itself becomes the model. Thus, the delivery of information can be conveyed because the resource person has acceptability because he has carried out material based on personal experience. Whereas for content related to nutritional topics, social workers must act as brokers who connect the community with nutritionists. As with the previous speakers, nutritionists who are speakers must also be models. That is, the material that has been delivered has been practiced before for himself. Thus, the resource person delivered the ideas based on experience and not just mere theory.

Each stage in action research shows that the dynamics of behavior change through social marketing requires planning and implementation of collaborative and multidisciplinary activities. This indicates that social workers do not work alone and are ready to work in teams when solving community problems in a participatory manner.

The social worker in carrying out social marketing needs to process the stages of social marketing with the marketing aspect itself. Gordon (2012, p. 125) explains that social marketing planning must consider the marketing mix that consist of circumstances, organization and competition, cost, consumer, process and channels/strategies. Previous marketing mix used "4 PS" (Product, Price, Place, Promotion) However, social marketing has its own characteristics and more complex from general marketing. Thus, the marketing mix evolved. Others argued some more "PS" consisted of process, physical evidence, and people. 4 PS became 7 PS. 7 PS did not enough because social markerter has to consider the human and the mezzo-macro system in maintaining social program. Instead of using the "PS" as single tools, the proposed model was considered the "PS" as one of usefull channels/strategies. Social marketer have to combine the channels/strategies with other important elements: circumstances, organization and competition, cost, consumer, and process.

Circumstances that consists of environmental factors is important to strengthen behavior changes of the target group. This study indentified community leaders academicians, health workers, practitioners, government agencies and the private sector as environmental factors. Stakeholders in community had crucial roles in maintaining behavior change of the target group. Carins \& Rundle-Thiele (2014) in their study about "Eating for the better: A social marketing review (2000-2012)" said that social and environmental aspect has to be considered in developing social marketing program. Putting social and environmental consideration could make behavior change program become more integrated.

To have a comprehensive way in identifying environmental factors, this research used ecological perspective. Gordon, et. al. (2018) mentioned that for developing social marketing program, social marketer could use ecological systems theory. The theory is an effective framework to analyse some crucial elements in mezzo-macro system. Gordon (2013) in his study explained how to work with upstream social marketing. Based on Ecological Perspective from Bronfenbrenner, there were principles and guidelines in studying mezzo-macro system. The principles and guidelines were: behaviour change, consumer research, insight, theory, segmentation and targeting, marketing mix, exchange, and competition. Kamin \& Anker (2014) had different argument. They used Bourdieu's capital theory to analyse macro system, especially by utilizing cultural capital as a tool to do social marketing. By using cultural capital, social worker who develop social marketing program would not only get macro level as the target system. Social worker could get micro level such as lack of interest and enthusiasm to change eating habit. More over, social worker also could change the mezzo level by giving the beneficiaries some skills to alter their behaviors towards eating habit in their family. From the perspective of social work discipline, Fahrudin (2018) argued those theories became basic knowledge for social worker to assess social function of society system and its elements. So that social workers could do professional social intervention.

Behavior change as a primary goal in this action response is not easy. Moreover, the behavior that will be changed is related to behavior change for participants in managing finances and providing food at home. To simplify the process, this action research uses the stages of social marketing which consist of several stages. Thus, various elements of social marketing can be packaged according to the needs of the target group. Regarding behavior change for participants in managing finances, based on one of the 
findings of this study, initially the discussion process of personal financial management included 12 topics discussed by Bajstelmit (2005):

i. Understanding the human life cycle, and how the human life cycle is related to financial consequences;

ii. Understand and be able to make family financial reports;

iii. Understand the problem of career choices in the future financial, health and welfare conditions;

iv. Understand inflation and its consequences;

v. Understand the concept of compound interest and how to lose the opportunity due to time;

vi. Understand the returns on various financial products from savings-bonds-stocks to mutual funds;

vii. Understand the process of consumptive credit applications such as credit cards - loans without car ownership loans, home ownership loans and approval processes from financial institutions such as credit-score checking and risk analysis;

viii. Understand life and health insurance products;

ix. Understand loss insurance products such as fire insurance, car accident insurance, and the others;

x. Understand the concept of retirement and can calculate pension requirements;

xi. Understand the concept of individual tax calculation;

xii. Understand the concept of inheritance planning.

But the problem of middle and lower-income families is very different from what is written in mainstream financial planning books such as Bajtelsmit (2005). This is because the amount of income in the lower middle class tends to be limited. The amount of financial allocation for daily needs will not be sufficient in real terms if it follows the healthy financial percentage standard according to the financial planning agreement of the Financial Planning Standard Board (FPSB) which is one of the references of Bajtelsmit (2005). Problems with middle-income income families are also related to health access, hygiene issues related to health risks, access to schools, access to employment opportunities, access to opportunities for economic improvement and the others. Until now there has not been a more comprehensive approach to conducting personal financial education targeting the middle and lower-class economic families. The existing approach for middle and lower-class economic families is a solution to increase their income, and after their income increases to the middle class, it is expected to follow the formal standards of international FPSB with the allocation of percentages to family income as follows:

i. Daily needs around $20-40 \%$;

ii. Payment of debt installments of $10-30 \%$;

iii. Saving and investing $10-30 \%$;

iv. The maximum lifestyle of $10 \%$.

\section{Having social activity: what is the benefit for beneficiaries?}

Regarding the context, this study found unique characteristics of the beneficiaries who live in sub urban area. After identifying some crucial factors in environment circumstances, social workers and other professionals in the team (as social marketers) have to assess organization and competition aspect in the community. As mentioned previously, there were stakeholders in community who have to get involved community. From them, social marketers identified the relation between stakeholders in community, the potentials, the need, and the main problem. Based on the identification of organization and competition aspect, social marketers cooperate with stakeholders in this study develop goals and objectives of programs. As the purpose of social marketing program, the goal of community program also changing beneficiaries' behavior in maintaining their daiy meals for long term health of their families. At this stage, social markerter mixed some aspect in social marketing program: channels/strategies, process, cost, and consumer. 
For having an effective social marketing process, social markerters in this study decided what kind of channels or strategies that fit with the context. As mentioned by Gordon (2012), elements of channels/strategies are product, price, place, promotion, people, policy, advocacy, lobbying, PR/media relation, and information. Based on research's result, social markerters prioritized some alements. They were product, price, place, promotion, people, policy, advocacy, and PR/media relation. Moreover, the first thing that have to be decided in this study was the place.

The place became the first priority. Based on the place, social markerter did not only get the channels for marketing the information. Social markerter also understood the context of social intervention. Based on the context, social markerter could decide other elements and strategies, such as consumers, people, product, price, (other kind of) place, promotion, media relations, and information.

In the stage of look of this study, social markerter assessed the need and the problem of change target. Regarding to the result, marketing strategy through large group approach would not be effective. Especially for the community that lack of "trust". In order to build the trust in the community, social marketers in this study decided to get 10 participants. One other important thing, the design, and delivery method of the message must be interesting. Benefits can be felt by participants depending on how the social product offering is offered. Moreover, social products, like general products, have real competitors to distract participants.

As stated by Cunha (in Fine, 1990, h.303), "since it is based on consumer wants and desires, it starts with an assumption of human needs and ends with means of satisfying them best." "The Roger Shoemaker Adoption Diffusion Paradigm" describes the relationship of attributes possessed by participants in the target group, to social marketing activities, and the decisions of individuals included in the target group. Thus, it can be seen whether participants are willing to accept or reject the message offered in social marketing. Knowledge Thus, social products to change the behavior of participants in this study indeed consider the results of the assessment.

Another crucial element is the (specific) "place", which is the place of activity as an effort so that marketing products or communication messages can reach service recipients. To change the behavior of beneficiaries, this study uses two types of products: tangible products and intangible products.

For tangible products, a place is a place of activity. This research uses Posyandu which is part of community assets. Service recipients can reach freely whereas the invisible product in this research is the transfer of knowledge and skill. To reach these products, the place concept in this study becomes more fluid because using social media to implement the behaviorism theory consists of modeling, conditioning, and imitation.

Beside ideas from "delivering knowledge", another social product in this action research is "practice". This product can be in the form of action and example of behavior. Therefore, social marketing that only relies on training for some time is not enough. Social media and home visit are the mainstays in this research. Even social workers collaborating with other stakeholders work together in developing visible products (social products that can be seen) in the form of a menu calendar. The calendar has been recorded as the intellectual property rights of the research team. In its application, the menu calendar facilitates social marketing activities, especially when carrying out modeling, imitation, and conditioning.

\section{Changing people's behavior through program oriented activities}

Social markting as one of a strategy of social intervention have a main purpose: changing behavior. Berfore chaning the behavior, there were several crucial aspect, such as knowledge and attitude. More over, Green and Kreuter (1991, p. 151) said a number of factors that influence a person's behavior, namely predisposing factors (causes that influence rational behavior or behavioral motivation), enabling factors (causes of behavior that facilitate motivation to be realized) and reinforcing factors (factors caused by behavior that provides continuous appreciation or incentives that contribute to the continuity of the behavior). Each of these factors still have several derivative factors. In predisposing 
factors, there are knowledge, attitudes, beliefs, values, and perceptions. In the driving factor, there are attitudes and behaviors from health workers or others. While supporting elements are the availability of resources, regulations, and skills needed by the target group. Changing those aspect also not an easy task. Therefor, social marketer has to fullfil principles and guidelines of social marketing. Beside behavior change, Gordon (2013) in his study mentioned some domain and principles. They were consumer research, insight, theory, segmentation and targeting, marketing mix, exchange and competition.

Previously mentioned in this article, the phase of look consisted of assessment activities. The results gave informations about several problems of community (table 1.). Based on the problems, social markerter analyzed the problems of the community, so that social markerter could gain deeper information about the problems of the change target. (See Table 1.)

Table 1. Insight About The Problem Of Change Target At Look and Think Stage

Predisposing Factors $\quad$ Reinforcing Factors $\quad$ Behavior

a mother had children

who were reluctant to consume formula milk

Some mothers had problems in dealing with children who were picky eater
- Some blocks often appear ice and food snacks
A mother had high cholesterol

a child had experienced malnutrition and often consume street food

Some mothers prefer to buy meals at the nearest stall, so the menu for their families depends on the menu at the stall.

Due to the assessment carried out in Ramadan, consumption of street foods was quite high $(\operatorname{Rp} 20,000$, Rp 30,000/day)
- Cadres at some neighbourhoods who were difficult to participate. They take action based on compensation that can take

- There were many people who stayed at rent house
- There were many cases of under red line weight, especially people who stayed at rent house

- Most mothers claim that their husbands consume 1 pack of cigarettes per day with a price range of IDR $16,000,-$ to IDR 18,000

There were datas from community profile that describe the behaviors, predisposing and reinforcing factors. However, there were no data about enabling factors. Eventhough a non government 
organization had informed that they delivered a cooking training to some young mothers, the skills did not appear at the look and think stage of this study. Based on the result of consumer research, social marketer that consist of some experts (social worker, economist, and nutritionist), moved to stage of act (implementation [segmentation and targeting, marketing mix, exchange and competition]) and evaluation. Of course, all the products in this study are things that can provide a solution to the problems that have been felt by participants in relation to problems in managing household finances and their relation to providing food at home for family members.

Based on assessment's result in the phase of look and think, the behavioral changes for 10 people as participants in the action research were using groups and individual approaches. Both approaches use two different "places": Posyandu (Pos Pelayanan Terpadu In Bahasa Indonesia or Integrated Services Post) and social media. Even social workers in this study also carried out a home visit to triangulate data.

The group approach have many advantages for marketing tools. However this approach has a weakness. Rahmat (2000, p. 149) wrote that one of the group's weakness is the existence of conformity. Kiesler and Kiesler (in Rahmat, 2000, p. 149) explained "conformity is a change in behavior or trust towards (norm) groups as a result of group pressure - real or imagined." Based on what was stated by Kiesler and Kiesler, packaging methods group discussion certainly must be monitored continuously in the effort to market the management of households for healthy living for the family. Moreover, a healthy lifestyle is still perceived as something that is difficult to reach for some people. Therefore, as mentioned earlier, this study does not use a single approach.

The product were three basic knowledge about financial management, self motivation to meal preparation at home, and nutrition. Social markerters delivered those subjects to beneficiaries in three events namely Training of Trainers. The purpose of the events were to make the participants became the main channel in community, so that information about healthy eating habit from home could be spread out massively in a long term.

For the early engagement with the beneficiaries, community workers also have to maintain the cost of beneficiaries who took social marketing tools voluntarily. For being part of marketing tools, the cost were used to be part of conditioning, imitation and modelling. Those approach were useful for maintaining behavior change through social marketing program. As stated by Gordon (2013), theory is an essential part in social marketing. This study was not only used ecological system theory. In order to get changes at micro level, this study also used the behaviorism and social cognitive theory.

MacFadyen, Stead, \& Hasting (1999, p. 2-3) explained the difference between social marketing and general marketing in competitive competition. Therefore the marketing mix in the form of the process of delivering products to participants plays important role in this social marketing. Variations in participant demand need to be considered by social workers. MacFadyen, Stead \& Hasting (1999, p. 67) state that social marketing that must be fulfilled by social workers is not just something new. Participants also become apathetic or resist. This has happened during the research process. Participants could not make meal plans and cook at home. There is a variety of social media that also support the apathy of participants. For example, frenzied social media that shows the stage of people's lives in the internet with a consumptive lifestyle. Even ready-made advertisements that are made more attractive. In fact, in the process of making advertisements, the food that is uploaded in the social media has gone through the editing process. The complexity contained in the process of implementing social marketing with its various uniqueness certainly demands the innovation of a social marketer. To overcome this, the behaviorism theory, social cognitive theory and ecological system theory were very helpful. Especially when the social workers used modeling and imitation as basic knowledge to do the program. The beneficiaries could see sincerity of social workers in doing andragogy approach in community. Since then, the truts of community could be developed for attitude of social workers towards beneficiaries. The beneficiaries in community empowerment through social marketing was not object of social services programs. In contrary, they are the subject of the program. Social workers, the experts and also stakeholders are the same learner in this changing process. 


\section{Conclusion}

This action research has been running for two years since the beginning of 2017 to the end of 2018 . The development of a conducive environment for families has complex dynamics to maintain their health. It was because the behavioral changing process is not as easy. Changes in participants basically must also begin with changes in social workers and their teams as perpetrators of change especially when working in a community setting that focuses on andragogy approaches.

In the midst of changing dynamics of complex behavior, social workers must also be consistent with the application of values in carrying out their profession. Moreover, the community system in this information era has become very fluid. Many ethical problems can be violated. For this reason, awareness of social workers on professionalism in carrying out their jobs is an essential aspect. Thus, the participant paradigm in action research as a subject becomes a fact. So that in the long process, behavioral changes that are expected in society to be able to develop a biologically, socially, psychologically and spiritually healthy environment can be sustainable. Delivering social services through professional practice is a crucial matter to re-build the trust of sub urban people towards "behavior change" programs.

\section{Acknowledgement}

This research was funded by Directorate of Research and Community Service, Universitas Indonesia and the Department of Social Welfare, Faculty of Social and Political Sciences, Universitas Indonesia. We would like also to acknowledge the contribution of many experts, practitioners, and students in this study. Especially for Retno Rini Zafira, IBU BISA and the participants who helped us in each stages of social marketing process in this research.

\section{References}

Amirin, T.M. (2016). Pokok-pokok Teori Sistem. Depok: PT Raja Grafindo Persada.

Amstrong, K. (2016). Fields of Blood. Bandung: Mizan Media Utama

Bajtelsmit, V. (2005), Personal finance: skills for life, John Wiley \& Sons, ISBN 0471781118, 9780471781110

Bongomin, G. O. C., Munene, J. C., Ntayi, J. M., \& Malinga, C.A., (2017) "Financial literacy in emerging economies: Do all components matter for financial inclusion of poor households in rural Uganda?", Managerial Finance, Vol. 43 Issue: 12, pp.1310-1331, https://doi.org/10.1108/MF-04-2017-0117

El-Maryam, P. S. Hubungan Karakteristik Anak, Karakteristik Orang Tua, Pola Makan, Aktivitas Fisik Dan Konsumsi Makanan Cepat Saji Dengan Kejadian Gizi Lebih Pada Siswa SD Muhammadiyah 6 Jakarta Selatan Tahun 2016.

Fahrudin, A. (2014). Pengantar Kesejahteraan Sosial. Bandung: PT. Refika Aditama.

Fahrudin, A. (2018). Perspektif Biopsikososial Untuk Asesmen Keberfungsian Sosial. Bandung: PT. Refika Aditama.

Fine, S.H. (1990). Social marketing: Promoting the causes of public and nonprofit agencies. United States of America: Allyn and Bacon.

Fitriani, A. (2018). "Faktor-Faktor Yang Mempengaruhi Pola Makan Mi Instan Di Kalangan Mahasiswa Di Yogyakarta Factors Influencing Instant Noodle Consumption Patterns Among Students In Yogyakarta." Medika Respati 13.

Fitzpatrick, T. (2005). New Theories of Welfare. London: Palgrave

FGD. (2017, Februari 25). Sawangan Baru. (Svm, Interviewer)

Gordon, R. (2012). Re-thinking and re-tooling the social marketing mix. Australasian Marketing Journal, 20(2), 122-126. $\quad$ Retrieved from https://search.proquest.com/docview/1027770394?accountid=17242

Gordon, R. (2013). Unlocking the potential of upstream social marketing. Journal of Social Marketing. 47 (9), 1525-1547. Retrieved from https://search.proquest.com 
Gordon, R. Butler, K, Cooper, P, Waitt, G, \& Magee, C. (2018). Look before you LIEEP Practicalities of using ecological systems social marketing to improve thermal comfort. Journal of Social Marketing. 8 (1), 99-119. Retrieved from https://search.proquest.com

Green, L. W., \& Kreuter, M. W. (1991). Health promotion planning: an educational and environmental approach. In Health promotion planning: an educational and environmental ABCD. Mayfield.

Gultom, M. M., et al. (2018). "Hubungan Konsumsi Makanan Jajanan Dengan Diare Pada Anak Di Sdn 3 Gogagoman Kecamatan Kotamobagu Barat Kota Kotamobagu." Jurnal Keperawatan 6(1).

Healy, K. (2005). Social Work Theories in Context. London, Palgrave Macmillan.

Kamin, T., \& Anker, T. (2014). Cultural capital and strategic social marketing orientations. Journal of Social Marketing, 4(2), 94-110. Retrieved from https://search.proquest.com/docview/1655514305?accountid=17242

Kotler, P. and Roberto, E.L.(1989). Social marketing: Strategies for changing public behavior. New York: The Free Press.

Krefting, L. (1991). Rigor in qualitative research: The assessment of truthworthiness. The American Journal of Occupational Therapy. Vol 45, no. 3, p. 214-222.

MacFadyen, L., Stead, M. and Hasting, G. (1999). Social marketing: A sypnosis by centre for social marketing. $\quad$ diakses $\quad$ pada $\quad$ tanggal $\quad 30$ januari 2006.http://www.marketing.strath.ac.uk/csm/about/synopsis.html

Machdum, S. V., et al. (2016). "Pengembangan Keterampilan Sosial dan Kewirausahaan pada Organisasi Pemuda Keagamaan di Depok." Sosio Konsepsia: 75-89.

Machdum, S. V., Agus, A. A., Ramzy, F. Z., \& Zafira, R. R. (n.d.). Peran Aktif Pemangku Kepentingan Pada Pelaksanaan Program Perlindungan Sosial Dalam Pemutakhiran Data Secara Kualitatif.

Mc Dowell, D., McMahon-Beattie, U., \& Burns, A., (2015) "Schoolinary art: practical cooking skills issues for the future", British Food Journal, Vol. 117 Issue: 2, pp.629-650, https://doi.org/10.1108/BFJ-05-2014-0161

Mufidah, N. L. (2012). "Pola konsumsi masyarakat perkotaan: studi deskriptif pemanfaatan foodcourt oleh keluarga." Jurnal Biokultur 2: 157-178.

Payne, M. (2005). Modern Social Work Theory (3rd ed). New York: Palgrave Macmillan.

Rahmat, J. (2000). Psikologi komunikasi. Bandung: PT Remaja Rosdakarya

Robbins, S. P., Chatterjee, P., \& Canda E.R. 2006. Contemporary Human Behavior Theory. USA:Pearson Education, Inc.

Stringer, E.T. (1999). Action research. Second Edition. London: Sage Publication.

Salleh, Ak Md H. A. Pg Md. (2015) "A comparison on financial literacy between welfare recipients and non-welfare recipients in Brunei", International Journal of Social Economics, Vol. 42 Issue: 7, pp.598-613, https://doi.org/10.1108/IJSE-09-2013-0210

Ulfani, D. H., et al. (2011). "Faktor-faktor sosial ekonomi dan kesehatan masyarakat kaitannya dengan masalah gizi underweight, stunted, dan wasted di Indonesia: Pendekatan ekologi gizi." Jurnal gizi dan pangan 6(1): 59-65.

Worsley, T., Wang, W. C., Wijeratne, P., Ismail, S., \& Ridley, S. (2015) "Who cooks from scratch and how do they prepare food?", British Food Journal, Vol. 117 Issue: 2, pp.664-676, https://doi.org/10.1108/BFJ-01-2014-0018

Zastrow, C. (2010). Introduction To Social Work and Social Welfare Belmont, Brooks/Cole Cengage Learning. 